\title{
Antimicrobial Activity of Dyed Wool Fabrics with Peanut Red Skin Extract Using Different Heating Techniques
}

\author{
H. M. Helmy, M. M. Kamel, K. Hagag, N. El-Hawary and N. S. El-Shemy* \\ Dyeing, Printing and Auxiliaries Department, Textile Research Division, National \\ Research Centre, El-Buhouth Street, Dokki, Cairo 12622, Egypt.
}

\begin{abstract}
I N THIS study, Peanut red skin (Arachis hypogaea L.) colorant extract was applied on wool fabric using alum (aluminum potassium sulfate) and ferrous sulfate as mordant. The effect of treatment variables such as dye concentration, $\mathrm{pH}$ of dyeing bath, time and temperature of dyeing process on the color strength and colorimetric data of dyed fabrics was examined. The fastness properties of dyed wool against rubbing, washing and light were evaluated. The use of metal mordants increased the color strength of the dyed fabrics. All mordants improved the fastness properties of the dyed fabrics toward perspiration, rubbing, washing, and light. Peanut red skin extract is a cationic dye Exhibits antimicrobial activity by virtue of its quaternary ammonium structure. So, dyed samples were tested for antibacterial activity using AATCC test method 100-2004. The dyed wool represented a high level of antibacterial activity. The extract of the Peanut red skin can be considered as a natural dye of acceptable fastness properties together with excellent antibacterial activity for woolen fabrics.
\end{abstract}

Keywords: Peanut red skin (Arachis hypogaea L.), Antibacterial activity, Wool dyeing, Ultrasonic, Microwave.

\section{Introduction}

Peanut red skin (Arachishypogaea L.) is the seed coat of peanut. Peanut red skins extract is high in Catechin and polyphenolic compounds including flavonoids, which means that they have antioxidant properties. Many researches on antioxidants recommend that may protect against oxidative stress, which has been involved in many diseases and cancers of humans. While the kernel of the peanut is a valuable product, the skin is a worthless by-product of peanut processing [18]. Skins have been used for feeding animal or as source of energy when burned. On the other hand, advanced research indicates that skin has a high content of phenolic compounds such as flavonoids, phenolic acids, procyanidins dimmers and oligomers as shown in Table 1. For all these reasons, this product has potential benefits for human health and beneficial biological activities [9-19].

The major cause of biodegradation of textile arts is microbial growth on textile materials, particularly natural products that led to development of antimicrobial technologies for preservative purposes. The increase of microorganisms on textiles inflicts a range of undesirable effects not only on the textile itself but also on the user. These effects include the generation of nasty odor, blotch and discoloration in the fabric, a decrease in fabric tensile strength and an increased possibility of impurities. These results have further accelerated the research on antimicrobial textiles with concentrate on improvement of permanent and forceful antibacterial finishing technologies [20].

In utilizing microwave method, the heating procedure happens through the electromagnetic field specifically to the material. This causes rapid heating in all parts of the material and reduces thermal gradients. Volumetric heating may also reduce reaction time and power saving. Microwave field and the dielectric heating are in charge of controlling on the capability of materials heating by utilizing microwave technique of electromagnetic theory and dielectric response Knowledge necessary to enhance the preparing of materials by utilizing microwave irradiation.

Regardless of, there are a lot of researchers in the area of using microwave in textile coloration; its use in dye extraction in addition to textile

*Corresponding author e-mail: nanaelshemy@hotmail.com

DOI: 10.21608/ejchem.2017.1601.1129

C2017 National Information and Documentation Center (NIDOC) 
printing is not yet satisfied [21-28]. The target of the current research is to assess microwave irradiation as a source of energy to extract colorants from Peanut red skin. The value of microwave

TABLE 1. peanut red skin (Arachishypogaea $L)$. as a novel dyeing extraction and its efficiency in increasing the dye fixation in comparative with the conventional methods (steaming and thermo-fixation) on different fabrics has been demonstrated.

\begin{tabular}{ll}
\multicolumn{1}{c}{ Property } & \multicolumn{1}{c}{ peanut red skin } \\
$\begin{array}{l}\text { Botanical } \\
\text { name }\end{array}$ & Arachishypogaea L \\
C.I. Name & Natural brown \\
Class & Alkaloids \\
Part used & Outer crust \\
$\kappa_{\max } \cdot(\mathrm{nm})$ & 350
\end{tabular}

\section{Experimental}

Materials

Natural coloring matter

Coloring substance used in this work was extracted from Peanut (Arachishypogaea L.) colorant

\section{Fabrics}

Wool fabrics $\left(172 \mathrm{~g} / \mathrm{m}^{2}\right)$ were supplied from Misr for Spinning and Weaving Company, ElMahalla El-Kobra, Egypt. The fabric was treated with a solution containing $2 \mathrm{~g} / 1$ nonionic detergent (Hostapal CV, Clariant), at 45-50 _C for $30 \mathrm{~min}$, then the fabrics were thoroughly rinsed with water and air dried at room temperature.

\section{Methods}

\section{Extraction of natural coloring matter}

The Peanut (Arachishypogaea L.) was peeling and the crust light brown was crushed to the powder form. Then the coloring matter was extracted using (20 g of the powder in 100 $\mathrm{ml}$ water) at the boil for one hour. At the end, the solution was filtered off and left to cool down.

\section{Dyeing method}

Dyeing of wool fabrics: Wool fabric samples (8.5g each) were dyed with the natural coloring matter extracted from Peanut (Arachishypogaea L.) at liquor ratio 1:50. Dyeing was carried out at $\mathrm{pH} 5.5$ for 60 minutes at $100^{\circ} \mathrm{C}$. The fabric samples were entered to the dyeing solution in a water bath at $70^{\circ} \mathrm{C}$ then raised to $100^{\circ} \mathrm{C}$. The fabrics were dyed for 60 minutes and the dyed samples were rinsed with cold water and washed
Polyphenolic Compounds in Peanut red Skin

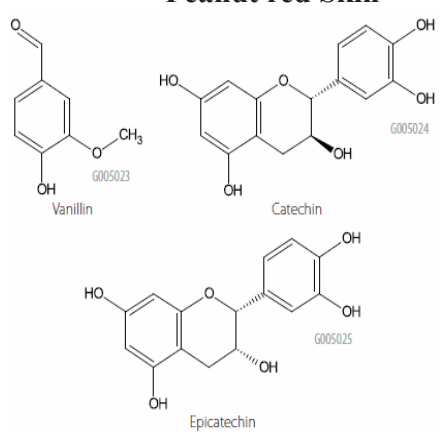

for 15 minutes in a bath containing $3 \mathrm{~g} / \mathrm{L}$ of nonionic detergent at $30^{\circ} \mathrm{C}$. Finally, the fabrics were rinsed and air dried.

\section{Apparatuses}

\section{Ultrasonic water bath}

A CREST Ultrasonic, TRU-SWEEPTM ultrasonic seat top cleaner bath, model $575 \mathrm{D}$ with a capacity 5.751 , was utilized. The trial setup utilized was made out of an electrical generator worked at a frequency of $38.5 \mathrm{kHz}$ and power going from $100 \mathrm{~W}$ average $/ 500 \mathrm{~W}$. The output power levels are from 100 up to $500 \mathrm{~W}$, and are supplied by three transducers at the bottom of the industrial grade tank. Digital advanced control of time $(0-90 \mathrm{~min})$, thermostatically controlled heater (encompassing to $80{ }^{\circ} \mathrm{C}$ ), power level and degas functions. The inward measurements of the tank were $11.5_{-} 6_{-} 6$ profundity and $292_{-} 152$

$152 \mathrm{~mm}$. The conventional dyeing device is Julabo SW 20 Julabo LABORTECHNIK GMBH D-77960 Seelbach/Germany, V/Hz 230/50/60.

\section{Microwave Heating System}

Extractions were carried out using microwave synthesis systems: Lab station, which is equipped with a magnetic stirrer, and a non-contact infrared continuous feedback temperature system, MILSTON, USA.

\section{Methods}

Dyeing of wool fabrics using conventional, ultrasonic and microwave methods

Wool fabric samples (0.5 g each) were dyed with the Peanut (Arachishypogaea L.) at liquor ratio 1:50. Dyeing was carried out at different 
concentrations of dye (1-9 g) /100 ml $\mathrm{H}_{2} \mathrm{O}, \mathrm{pH}$ values $(2.5-9.5)$, temperatures $\left(40-80{ }^{\circ} \mathrm{C}\right)$, and duration time (40- $80 \mathrm{~min})$ as detailed in the text. In case of ultrasonic for comparison, the same conditions of dyeing were carried out using ultrasonic dyeing (US) method and microwave dyeing method. Then the dyed samples were rinsed with cold water and washed for $25 \mathrm{~min}$ in a bath containing $2 \mathrm{~g} / \mathrm{l}$ of non-ionic detergent (Hostapal CV, Clariant), at 45-50 C. Finally, the fabrics were rinsed with water and air dried.

\section{Antibacterial test}

The antibacterial and antifungal studies of treated fabrics with nanoparticles were accomplished in triplicates using standard methods (AATCC TM100).

The treated fabric $(0.5 \mathrm{~g})$ was introduced into $20 \mathrm{ml}$ nutrient broth and inoculated with the respective bacterial strains followed by overnight ( $24 \mathrm{hrs}$ ) incubation at $37^{\circ} \mathrm{C}$. Growth of the bacterial strains was determined spectrophotometrically (OD660) in presence of the treated fabric against a blank of un-inoculated sterile medium. Similarly, the fungal strains inoculated into potato dextrose broth and incubated for $48 \mathrm{hrs}$ at $28^{\circ} \mathrm{C}$ in a shaker incubator followed by measurement of OD450 against a blank of un-inoculated sterile medium. Before recording the OD of the respective media after incubation, the culture tubes were shaken thoroughly in order to bring microorganisms into suspension.

Optical density is directly proportional to the number of microorganisms (bacteria or fungi) in the medium. The percentage of reduction of the microorganisms was expressed as follows.

$\mathrm{R}=(\mathrm{B}-\mathrm{A}) / \mathrm{B} \times 100$, where; $\mathrm{R}=$ percentage of reduction of microbial population; $\mathrm{B}=$ absorbance of the media inoculated with microbes and $\mathrm{A}=$ absorbance of the media inoculated with microbes and treated fabric. (Baliarsingh, Behera, Jena, Das, \& Das, 2015)

\section{Colorimetric measurements}

The color strength $(\mathrm{K} / \mathrm{S})$

The color strength $(\mathrm{K} / \mathrm{S})$ in visible region of the spectrum (400-700) nm was calculated based on Kubelkae- Munk equation:

$$
\frac{K}{S}=\frac{(1-R) 2}{2 R}
$$

Where, $(\mathrm{K})$ is adsorption coefficient, $(\mathrm{R})$ is reflectance of dyed sample and $(\mathrm{S})$ is scattering coefficient.

The colorimetric properties of dyed fabrics were obtained with Hunter Lab DP-9000 ColorSpectrophotometer

\section{Color data CIELAB space}

Colour-difference formula CIE (L*, $\left.\mathrm{a}^{*}, \mathrm{~b}^{*}\right)$ :

The total difference CIE (L*, a*, b*) was measured using the Hunter-Lab spectrophotometer (model: Hunter Lab DP-9000).

CIE (L*, $\left.a^{*}, b^{*}\right)$ between two colours each given in terms of $\mathrm{L}^{*}, \mathrm{a}^{*}, \mathrm{~b}^{*}$ is calculated from:

$\mathrm{L}^{*}$ value: indicates lightness, $(+)$ if sample is lighter than standard, (-) if darker.

$a^{*} \& b^{*}$ values: indicate the relative positions in CIE Lab space of the sample and the standard, from which some indication of the nature of the difference can be seen.

\section{Fastness testing}

Washing fastness: The colour fastness to washing was determined according to ISO 105CO2:1989 test method [29]. The washing fastness tests were conducted in a launderometer (ATLASGermany) using $5 \mathrm{~g} / \mathrm{L}$ nonionic detergent at $50^{\circ} \mathrm{C}$ for $45 \mathrm{~min}$., the liquor ratio was 1:50. The composite specimen was removed, rinsed with running tap water, squeezed, then opened and dried in air. It included the test specimen and the two adjacent fabrics in contact of the main sample. The gray scale was used to assess the colour change of the dyed sample and the staining of the two adjacent undyed fabrics were cotton and wool.

Light fastness: This test was evaluated according to ISO 105-B02: 1988 test method [이] using a carbon arc lamp. Samples were exposed to a continuous light for 35 hours in order to determine the degree of colour resistance to light photo- degradation.

Rubbing fastness: Rubbing fastness was determined according to test method ISO 105-X12: 1987 [31] using a crock-meter under conditions for determination of dry and wet fastness.

\section{Results and Discussion}

Over the last decade, many authors research a new offering a different effective heat source of several chemical reactions and procedures. It has several advantages comparing to traditional heating such as; non-contact heat, energy transfer 
instead of heat transfer, higher heating rate, quick start-up and stopping of heating, homogeneous heating with negligible thermal gradients, choosy heat properties, reversal thermal effects (heating start from the internal of material body), energy savings and higher yields in shorter reaction time. In this context, applying of different heating resource in textile coloration was of interest, thus, exploiting IR, Microwave (MW) irradiation as well as Ultrasonic heating (UH) in dye extraction from peanut red skin as a natural colorant was carried out and applied it as a dye to wool dyeing .

\section{Effect of extracted dye concentration}

Table 2 shows the results of K/S and coloring data of dyed wool fabrics with Peanut red skin extract using three different heating methods namely; IR, Ultrasonic and Microwave with different dye extract concentrations. From these results, it can be concluded that the higher $\mathrm{K} / \mathrm{S}$ was obtained with IR heating method (5.32 at $5 \mathrm{~g} / 100$ $\mathrm{ml}$. dye extract conc.) then microwave heating method (5.08 at $3 \mathrm{~g} / 100 \mathrm{ml}$. dye extract conc.) and finally ultrasonic heating method (3.32 at $3 \mathrm{~g} / 100$ $\mathrm{ml}$. dye extract conc.). However, the MW has the best result than UH at the same concentration this may be attributed to microwave irradiation which saves energy and time greatly. While in IR, it gives higher K/S at higher concentration and we observed that it causes a harsh filling and it affects on tensile strength of the fabric.

TABLE 2. Effect of dye concentration on color strength and colorimetric data of wool fabric dyed with Peanut red Skin (Arachishypogaea L.) using different heating methods.

\begin{tabular}{cccccc}
\hline Heating methods & Dye extracts conc. (g/100 ml.) & K/S & $\mathbf{L}^{*}$ & $\mathbf{a}^{*}$ & $\mathbf{b}^{*}$ \\
\hline \multirow{2}{*}{ IR } & 1 & 3.03 & 64.97 & 9.02 & 15.19 \\
Heating & 3 & 2.75 & 64.81 & 9.60 & 15.22 \\
& 5 & 5.32 & 51.70 & 14.30 & 17.01 \\
& 7 & 3.23 & 64.45 & 9.19 & 16.43 \\
Ultrasonic heating & 9 & 2.80 & 66.94 & 8.32 & 15.19 \\
& 1 & 2.98 & 59.56 & 12.16 & 13.18 \\
& 3 & 3.32 & 63.96 & 9.13 & 14.63 \\
& 5 & 3.32 & 62.24 & 10.97 & 15.96 \\
& 7 & 3.21 & 65.04 & 9.44 & 15.91 \\
& 9 & 3.21 & 65.31 & 9.14 & 16.46 \\
Microwave heating & 1 & 4.73 & 53.25 & 13.54 & 13.58 \\
& 3 & 5.08 & 57.73 & 11.39 & 16.15 \\
& 5 & 5.08 & 55.23 & 12.63 & 16.29 \\
\hline & 7 & 4.71 & 58.49 & 11.22 & 16.15 \\
\hline
\end{tabular}

Dyeing cond.: $\mathrm{pH} 4.5$, L.R. 1:40, $80^{\circ} \mathrm{C}$, for $60 \mathrm{~min}$ at different conc. (1-99/100ml.).

\section{Effect of time on dye extracted}

Table 3 shows the results of K/S and coloring data of dyed wool fabrics with Peanut red skin extracted by using three different heating methods namely; IR, Ultrasonic and Microwave at different dyeing time. From these results, it can be concluded that the higher $\mathrm{K} / \mathrm{S}$ was obtained with microwave heating method (8.83 at 6 min.) than IR heating method (7.18 at $80 \mathrm{~min}$.) and finally ultrasonic heating method (3.63 at $80 \mathrm{~min}$.). From this table, it can be noticed that $\mathrm{K} / \mathrm{S}$ increased with increasing the time of dyeing except in case of microwave heating method as the $\mathrm{K} / \mathrm{S}$ decreased after $6 \mathrm{~min}$. This may be attributed to microwave irradiation. The microwave radiation helps and influences the penetration of the shading furthermore the depth to which the infiltration happens in the fabric. This improves microwave than conventional shading methodology. 
From Table 3, it can be observed that the results of color data $\left(\mathrm{L}^{*}, \mathrm{a}^{*}\right.$ and $\left.\mathrm{b}^{*}\right)$ of the dyed wool fabrics in different dyeing time can be explained as follow; $\mathrm{L}^{*}$ values decreased with increasing the time of dyeing in the 3 different heating methods which mean more dark color. Most values of $a^{*}$ and $b^{*}$ increased with increasing the time of dyeing which is indication that color turned to more yellowish red color.

TABLE 3. Effect of time of dyeing on color strength and colorimetric data of wool fabric dyed with Peanut red Skin (Arachishypogaea L.) using different heating methods.

\begin{tabular}{cccccc}
\hline Heating methods & Dyeing time (min.) & K/S & $\mathbf{L}^{*}$ & $\mathbf{a}^{*}$ & $\mathbf{b}^{*}$ \\
\hline \multirow{2}{*}{ IR } & 40 & 2.54 & 62.48 & 11.77 & 13.80 \\
& 50 & 4.98 & 51.95 & 14.79 & 13.96 \\
60 & 4.64 & 49.77 & 14.93 & 13.92 \\
70 & 6.43 & 45.89 & 15.66 & 14.27 \\
Ultrasonic heating & 7.18 & 45.90 & 15.66 & 14.36 \\
& 40 & 2.64 & 61.90 & 13.00 & 12.96 \\
& 50 & 2.93 & 61.54 & 12.44 & 13.31 \\
& 60 & 2.36 & 60.92 & 12.58 & 13.75 \\
Microwave heating & 70 & 2.52 & 59.02 & 14.11 & 14.10 \\
& 80 & 3.63 & 56.54 & 15.34 & 15.70 \\
& 4 & 3.93 & 51.07 & 17.93 & 12.72 \\
& 5 & 4.93 & 47.55 & 19.37 & 13.52 \\
& 7 & 7.93 & 37.87 & 25.06 & 16.67 \\
& 8 & 7.77 & 37.56 & 23.41 & 15.91 \\
\end{tabular}

Dyeing cond.: pH 4.5, L.R.: 1:40, $80^{\circ} \mathrm{C}$, Conc. $5 \mathrm{gm} / 100 \mathrm{ml}$ at different time. (40-80 min) for IR\&US while (4-8min) for microwave.

\section{Effect of extracted dye path $\mathrm{pH}$}

Table 4 shows that the $\mathrm{pH}$ values of the dyeing bath have some effects on the color of the dyed wool fabrics with Peanut red Skin. When $\mathrm{pH}$ values increased most values of $\mathrm{a}^{*}$ and $\mathrm{b}^{*}$ increased in the positive direction which means the color of fabric was turned to reddish yellow color and $\mathrm{L}^{*}$ values decreased with increasing $\mathrm{pH}$ in the three different heating methods and the color of fabric become darker.

TABLE 4. Effect of pH of dyeing bath on color strength of wool fabric dyed with Peanut red Skin (Arachishypogaea L.) using different heating methods.

\begin{tabular}{cccccc}
\hline Heating methods & Dyeing bath $\mathbf{~ H ~}$ & $\mathbf{K} / \mathbf{S}$ & $\mathbf{L}^{*}$ & $\mathbf{a}^{*}$ & $\mathbf{b}^{*}$ \\
\hline \multirow{2}{*}{ IR } & 2.5 & 5.69 & 48.35 & 18.90 & 18.05 \\
& 4.5 & 7.32 & 48.62 & 14.79 & 18.75 \\
& 6.5 & 8.85 & 48.18 & 10.00 & 16.86 \\
Ultrasonic heating & 8.5 & 9.02 & 43.23 & 20.18 & 19.65 \\
& 9.5 & 10.42 & 39.83 & 20.34 & 19.88 \\
& 2.5 & 3.04 & 63.14 & 8.80 & 14.95 \\
& 4.5 & 3.18 & 60.83 & 10.47 & 14.40 \\
& 6.5 & 3.28 & 63.22 & 12.52 & 15.83 \\
Microwave heating & 8.5 & 3.48 & 56.38 & 14.35 & 15.17 \\
& 9.5 & 3.96 & 63.49 & 15.61 & 18.45 \\
& 2.5 & 4.64 & 61.73 & 9.54 & 19.25 \\
& 4.5 & 4.71 & 55.36 & 11.68 & 16.26 \\
\hline
\end{tabular}

Dyeing conds.: Dye conc. $5 \mathrm{gm} / 100 \mathrm{ml}$, L.R. $1: 40,80^{\circ} \mathrm{C}, 6 \mathrm{~min}$ for microwave irradiation and $80 \mathrm{~min}$. For IR and Ultrasonic, at different $\mathrm{pH}$. 
From these results it can be noticed that wool fabrics dyed in alkali bath possessed reddish and more yellow character and bigger chromatic values compared with that in acidic dyeing bath. The effect of dyeing bath $\mathrm{pH}$ could be attributed to the correlation between Peanut red skin structure and wool fabric. Since the Peanut red Skin is a water soluble dye containing cationic quaternary ammonium salt, it would interact ionically with the carboxyl end groups of wool fabric at alkaline $\mathrm{pH}$ (8.5 and 9.5) via ion exchange reaction. The number of available anionic sites on wool fabric in alkaline conditions is relatively larger than that in acidic conditions, and thus the exhaustion of the cationic Peanut red skin extract was increased in alkaline dyeing solutions (Scheme 1).<smiles>CNC(CSSCC(C(C)=O)N(C)C)C(C)=O</smiles>

\section{Effect of temperature on dye extract}

The effect of temperature on the color strength $(\mathrm{K} / \mathrm{S})$ of wool fabrics was occurred at different temperatures $\left(40,50,60,70\right.$ and $\left.80^{\circ} \mathrm{C}\right)$. As shown in Table 5, it is clear that color values increased with increasing the temperature from 40 to $80^{\circ} \mathrm{C}$. When dyed at lower temperature, wool fabric color was bright beige. When raising the temperature, the conglomeration of colorant molecules declined, and the diffusion of peanut red skin extract into the wool fibers could happened very easily and quickly at a higher temperature, which cause the change of lightness, saturation and color difference. From these results, it can be concluded that the higher K/S was obtained with microwave

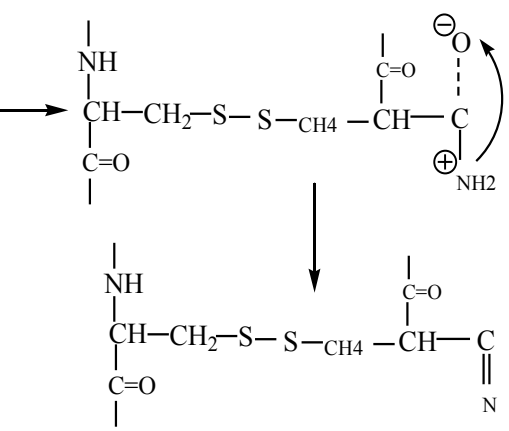

heating method $\left(9.61\right.$ at $\left.80^{\circ} \mathrm{C}\right)$ then IR heating method $\left(6.48\right.$ at $\left.80{ }^{\circ} \mathrm{C}\right)$ and finally ultrasonic heating method $\left(3.72\right.$ at $\left.80^{\circ} \mathrm{C}\right)$. From this table, it can be noticed that $\mathrm{K} / \mathrm{S}$ increased with increasing the Dyeing bath temperature.

The results of color data of these samples can be explained as follow; for the three different heating methods $L^{*}$ values decrease with increasing the temperature which mean darker color. This may be due to at higher temperature the diffusion of peanut red skin extract into the wool fibers occurred very easily and quickly which cause more dye molecule penetrated into the fibre that causes darker color.

TABLE 5. Effect of temperature of dyeing bath on color strength of wool fabric dyed with Peanut red Skin (Arachishypogaea L.) using different heating methods.

\begin{tabular}{cccccc}
\hline Heating method & Dyeing bath temperature $\left({ }^{\mathbf{O}} \mathbf{C}\right)$ & $\mathbf{K} / \mathbf{S}$ & $\mathbf{L}^{*}$ & $\mathbf{a}^{*}$ & $\mathbf{b}^{*}$ \\
\hline \multirow{3}{*}{ IR } & 40 & 2.02 & 69.01 & 7.58 & 15.26 \\
heating & 50 & 2.42 & 66.74 & 8.54 & 16.24 \\
& 60 & 2.49 & 65.70 & 9.42 & 16.83 \\
& 70 & 4.00 & 52.30 & 17.26 & 13.08 \\
Ultrasonic heating & 80 & 6.48 & 46.30 & 17.62 & 14.57 \\
& 40 & 2.34 & 64.28 & 10.90 & 13.31 \\
& 50 & 2.36 & 67.73 & 8.02 & 17.01 \\
& 60 & 2.70 & 65.39 & 9.33 & 18.85 \\
& 70 & 3.65 & 60.96 & 11.50 & 19.99 \\
Microwave heating & 80 & 3.72 & 54.89 & 15.66 & 14.96 \\
& 40 & 2.09 & 66.83 & 10.22 & 11.93 \\
& 50 & 3.82 & 47.77 & 21.41 & 13.27 \\
& 60 & 3.90 & 49.39 & 20.69 & 13.31 \\
& 70 & 6.25 & 46.09 & 18.79 & 14.85 \\
\hline
\end{tabular}

Dyeing conds.: Dye conc. $5 \mathrm{gm} / 100 \mathrm{ml}$, pH 9.5, L.R. 1:40, $80 \mathrm{~min}$ for ultrasonic and IR and 6 min. for microwave irradiation, at different temperature. 


\section{Effect of mordants}

Table 6 illustrates the results of different mordants namely ferrous sulphate and alum of dyed wool fabrics using Peanut red Skin extract with pre and simultaneous mordanting methods and its effect on K/S and color data. This table indicated that best results of $\mathrm{K} / \mathrm{S}$ were achieved with IR heating method using pre-alum (21.32) then microwave heating method using sem.- alum (14.46) and finally ultrasonic heating method using Sem.- $\mathrm{Fe}_{2} \mathrm{SO}_{4}$ (8.97).
From Table 6, it is obvious that there is a significant change in $\mathrm{K} / \mathrm{S}$ for the dyed wool fabrics mordanted with alum as a result of metal complex formation between the dye and the mordant used. Also, with ferrous sulfate, the color was darker and duller. This may be attributed to the change of ferrous sulfate into a ferric form by reacting with oxygen of the air. Ferrous and ferric forms coexist on the fibers and their spectra overlapped, resulting in a shift of $\lambda_{\max }$ and consequently the color change to a darker shade [32].

TABLE 6. Effect of using different mordants on color strength of wool fabric dyed with Peanut red Skin (Arachishypogaea L.) using different heating methods.

\begin{tabular}{clcccc}
\hline \multicolumn{1}{c}{ Mordant type } & $\mathbf{K} / \mathbf{S}$ & $\mathbf{L}$ & $\mathbf{a}^{*}$ & $\mathbf{b}^{*}$ \\
\hline \multirow{3}{*}{ IR } & Blank & 6.48 & 46.30 & 17.62 & 14.57 \\
& Pre-alum & 21.32 & 29.01 & 15.52 & 14.49 \\
& Sem.- alum & 12.06 & 60.92 & 13.73 & 39.48 \\
& Pre $\mathrm{Fe}_{2} \mathrm{SO}_{4}$ & 11.78 & 32.56 & 9.19 & 7.82 \\
& Sem.- $\mathrm{Fe}_{2} \mathrm{SO}_{4}$ & 18.49 & 37.04 & 6.25 & 17.91 \\
& Blank & 3.72 & 54.89 & 15.66 & 14.96 \\
\multirow{3}{*}{ Ultrasonic heating } & 7.07 & 47.21 & 13.64 & 14.42 \\
& Pre- alum & 7.64 & 50.26 & 11.47 & 18.81 \\
& Sem.- alum & 3.37 & 64.03 & 7.26 & 16.43 \\
& Pre- $\mathrm{Fe}_{2} \mathrm{SO}_{4}$ & 8.97 & 47.94 & 3.99 & 13.54 \\
& Sem.- $\mathrm{Fe}_{2} \mathrm{SO}_{4}$ & 9.61 & 42.81 & 18.17 & 16.31 \\
& Blank & 9.71 & 23.26 & 7.55 & 5.84 \\
& Pre- alum & 14.46 & 51.56 & 13.38 & 34.81 \\
& Sem.- alum & 5.28 & 49.42 & 4.80 & 9.21 \\
& Pre- $\mathrm{Fe}_{2} \mathrm{SO}_{4}$ & 11.21 & 42.52 & 3.83 & 12.96 \\
\hline
\end{tabular}

Dyeing conds.: Dye conc. $5 \mathrm{gm} / 100 \mathrm{ml}$, pH 9.5, L.R. 1:40, $80 \mathrm{~min}$ for ultrasonic and IR and 6 min. for microwave irradiation, at $80^{\circ} \mathrm{C}$ and concentration of mordant $1.8 \mathrm{~g} / \mathrm{L}$.

The color of fabrics is dependent on type of mordant used. By addition of ferrous Sulphate L* values decrease compared to the control sample which means that color of fabric turned to a darker shade. It is noted that after mordanting the greenish of wool fabric increased obviously. It is clear from these data that ferrous sulfate mordanted wool fabrics yielded darker and less bright shade, as it is concluded from color measurements in table 6 for the ferrous Sulphate mordanted dyed fabrics. These changes of color values may be due to the impact of ferrous sulfate on dye chemical structure. The color of wool fabrics mordanted with ferrous sulphate was significantly changed as function of iron content on fabrics, by growing the iron content the values of $a^{*}$ increased in the negative direction while $b^{*}$ increased in the positive direction. The color of wool fabrics mordanted with ferrous sulphate was turned to greenish yellow and became darker at using ferrous sulphate as higher iron content was recorded.

On the other hand, by the addition of alum $\mathrm{L}^{*}$ values decreased compared to the blank in case of pre- alum for the 3 heating methods which mean more dark color, but in case of simultaneousmordanting for the 3 heating methods the $\mathrm{L}^{*}$ values increased compared to the blank which mean lighter color. For $\mathrm{a}^{*}$ and $\mathrm{b}^{*}$ values the addition of alum the color turn to more reddish yellow color compared to the control sample in case of simultaneous- mordanted alum but in case of pre- mordanted alum the color of fabric turned to less reddish yellow color. These changes of color values may be due to the impact of alum salt on dye chemical structure.

Egypt.J.Chem. Special Issue (2017) 


\section{Fastness properties}

Table 7 shows the wash-fastness, rub-fastness, Perspiration fastness and light fastness properties of wool fabrics dyed with Peanut red Skin(without and with mordant). Dyeing with Peanut red skin showed excellent washing, perspiration and light fastness except in case of blank using IR and Ultrasonic heating method. As it was expected using mordants gave good improvement in most of color fastness properties used in case of IR and Ultrasonic heating methods except in case of rubbing fastness with IR heating method which gave fair results. Also, it can be noticed that the best results of color fastness properties were achieved with microwave heating with or without using mordants.

The chemistry of bonding of PES extract to wool fiber is complex. It involves chemical bond, H-bonds, and hydrophobic interactions. Generally, mordants help binding of PES extract to wool fabric by forming a chemical bridge from coloring matter to the fiber, thus improving the staining ability of a PES extract along with increase in its fastness properties (see Scheme 1).

TABLE 7. Fastness properties of mordanted dyed wool fabrics with natural coloring matter extracted from Peanut red Skin (Arachishypogaea L.) using different heating methods.

\begin{tabular}{|c|c|c|c|c|c|c|c|c|c|c|}
\hline \multirow{3}{*}{$\begin{array}{l}\text { Heating } \\
\text { methods }\end{array}$} & \multirow{3}{*}{ Dyeing condition } & \multicolumn{2}{|c|}{ Washing } & \multicolumn{4}{|c|}{ Perspiration } & \multicolumn{2}{|c|}{ Rubbing } & \multirow{3}{*}{ Light } \\
\hline & & \multirow{2}{*}{ Alt } & \multirow{2}{*}{ St. } & \multicolumn{2}{|c|}{ Acidic } & \multicolumn{2}{|c|}{ Alkaline } & \multirow{2}{*}{ Dry } & \multirow{2}{*}{ Wet } & \\
\hline & & & & Alt & St. & Alt & St. & & & \\
\hline \multirow{5}{*}{$\begin{array}{c}\text { IR } \\
\text { Heating }\end{array}$} & Blank & 4 & 3 & 3 & 3 & 3 & 3 & $2-3$ & 2 & $5-6$ \\
\hline & Pre alum & $4-5$ & $4-5$ & $4-5$ & $4-5$ & $4-5$ & $4-5$ & 3 & $2-3$ & $5-6$ \\
\hline & Sim. Alum & $4-5$ & $4-5$ & $4-5$ & $4-5$ & $4-5$ & $4-5$ & 3 & $2-3$ & $5-6$ \\
\hline & Pre $\mathrm{Fe}_{2} \mathrm{SO}_{4}$ & $4-5$ & $4-5$ & $4-5$ & $4-5$ & $4-5$ & $4-5$ & 3 & $2-3$ & $5-6$ \\
\hline & Sim. $\mathrm{Fe}_{2} \mathrm{SO}_{4}$ & $4-5$ & $4-5$ & $4-5$ & $4-5$ & $4-5$ & $4-5$ & 3 & $2-3$ & $5-6$ \\
\hline \multirow{5}{*}{$\begin{array}{l}\text { Ultrasonic } \\
\text { heating }\end{array}$} & Blank & $3-4$ & $3-4$ & $4-5$ & $4-5$ & $4-5$ & $4-5$ & $2-3$ & $2-3$ & $5-6$ \\
\hline & Pre alum & $4-5$ & $4-5$ & $4-5$ & $4-5$ & $4-5$ & $4-5$ & $4-5$ & $4-5$ & $5-6$ \\
\hline & Sim. Alum & $4-5$ & $4-5$ & $4-5$ & $4-5$ & $4-5$ & $4-5$ & $4-5$ & $4-5$ & $5-6$ \\
\hline & Pre $\mathrm{Fe}_{2} \mathrm{SO}_{4}$ & $4-5$ & $4-5$ & $4-5$ & $4-5$ & $4-5$ & $4-5$ & $4-5$ & $4-5$ & $5-6$ \\
\hline & Sim. $\mathrm{Fe}_{2} \mathrm{SO}_{4}$ & $4-5$ & $4-5$ & $4-5$ & $4-5$ & $4-5$ & $4-5$ & $4-5$ & $4-5$ & $5-6$ \\
\hline \multirow{5}{*}{$\begin{array}{l}\text { Microwave } \\
\text { heating }\end{array}$} & Blank & 5 & 5 & 5 & 5 & 5 & 5 & 5 & 5 & $5-6$ \\
\hline & Pre alum & 5 & 5 & 5 & 5 & 5 & 5 & 5 & 5 & $5-6$ \\
\hline & Sim. Alum & 5 & 5 & 5 & 5 & 5 & 5 & 5 & 5 & $5-6$ \\
\hline & Pre $\mathrm{Fe}_{2} \mathrm{SO}_{4}$ & 5 & 5 & 5 & 5 & 5 & 5 & 5 & 5 & $5-6$ \\
\hline & Sim. $\mathrm{Fe}_{2} \mathrm{SO}_{4}$ & 5 & 5 & 5 & 5 & 5 & 5 & 5 & 5 & $5-6$ \\
\hline
\end{tabular}

Change of color after different washing cycles

Table 8 illustrated the results of change of color $(\Delta \mathrm{E})$ after many washing cycles $(5,10,15,20$ and 25). From these results, it can be observed that wool fabric dyed with natural coloring matter and extracted from peanut red Skin using IR heating and ultrasonic heating methods achieved best results when using pre-mordanting method with alum and ferrous sulphate respectively. On the other hand, wool fabric dyed with natural coloring matter and extracted from peanut red skin using microwave heating method achieved best results when using simultaneous mordanting method

Egypt.J.Chem. Special Issue (2017) with alum and ferrous Sulphate, respectively. For all heating methods, the best results was achieved with microwave heating method then ultrasonic heating method and worst one is Infra-red heating method. The best results were achieved with simultaneous mordanting method with alum using microwave heating method after 25 washing cycles (2.35). Alternatively, the worst results were given with simultaneous mordanting method with alum using Infra-red heating method after 25 washing cycles (15.73). From these results, it can be concluded that results of $(\Delta \mathrm{E})$ depending on the type of mordant used and kind of heating method used during dyeing and mordanting. 
TABLE 8. Effect of using different mordants on the color change for wool fabric dyed with natural coloring matter extracted from Peanut red Skin using different heating methods after 5, 10, 15, 20 and 25 washing cycles.

\begin{tabular}{|c|c|c|c|c|c|c|c|}
\hline \multirow{2}{*}{$\begin{array}{l}\text { Heating } \\
\text { methods }\end{array}$} & \multirow[b]{2}{*}{ Mordant type } & \multicolumn{6}{|c|}{ Change of color $(\Delta \mathbf{E})$} \\
\hline & & $\begin{array}{l}\text { without } \\
\text { washing }\end{array}$ & $5 W$ & $10 \mathrm{~W}$ & $15 \mathrm{~W}$ & $20 W$ & $25 \mathrm{~W}$ \\
\hline \multirow{6}{*}{ IR } & Blank & 0 & 0.62 & 0.76 & 1.81 & 2.39 & 2.69 \\
\hline & Pre- alum & 0 & 0.64 & 2.00 & 2.13 & 2.28 & 2.68 \\
\hline & Sim- alum & 0 & 9.19 & 12.41 & 14.27 & 15.45 & 15.73 \\
\hline & Pre- $\mathrm{Fe}_{2} \mathrm{SO}_{4}$ & 0 & 1.40 & 1.63 & 1.79 & 1.93 & 2.69 \\
\hline & Sim- $\mathrm{Fe}_{2} \mathrm{SO}_{4}$ & 0 & 3.94 & 4.07 & 4.20 & 5.07 & 6.22 \\
\hline & Blank & 0 & 3.18 & 3.43 & 3.94 & 6.76 & 8.83 \\
\hline \multirow{4}{*}{ Ultrasonic heating } & Pre- alum & 0 & 1.02 & 2.08 & 2.61 & 2.90 & 3.95 \\
\hline & Sim- alum & 0 & 1.42 & 1.66 & 3.20 & 4.17 & 6.06 \\
\hline & Pre- $\mathrm{Fe}_{2} \mathrm{SO}_{4}$ & 0 & 1.30 & 2.14 & 2.64 & 2.86 & 4.86 \\
\hline & $\mathrm{Sim}-\mathrm{Fe}_{2} \mathrm{SO}_{4}$ & 0 & 3.74 & 3.74 & 3.82 & 4.25 & 6.78 \\
\hline \multirow{5}{*}{$\begin{array}{l}\text { Microwave } \\
\text { heating }\end{array}$} & Blank & 0 & 0.77 & 1.06 & 4.71 & 4.56 & 5.86 \\
\hline & Pre- alum & 0 & 2.48 & 3.70 & 3.97 & 4.25 & 4.73 \\
\hline & Sim- alum & 0 & 1.04 & 1.37 & 1.62 & 1.62 & 2.35 \\
\hline & Pre- $\mathrm{Fe}_{2} \mathrm{SO}_{4}$ & 0 & 1.11 & 1.98 & 2.47 & 2.76 & 3.15 \\
\hline & Sim- $\mathrm{Fe}_{2} \mathrm{SO}_{4}$ & 0 & 0.77 & 2.00 & 2.33 & 2.34 & 2.41 \\
\hline
\end{tabular}

(W) : washing cycle.

\section{Infrared spectrum results}

As shown in Fig. 1, the characteristic peaks of peanut red skin extracted macromolecule, appear at $3406 \mathrm{~cm}^{-1}$ for $\mathrm{O}-\mathrm{H}$ broad stretching vibration, $2924 \mathrm{~cm}^{-1}$ (C-H stretching of aromatic ring), while peak at $2856 \mathrm{~cm}^{-1}(\mathrm{C}-\mathrm{H}$ wagging for Aliphatic group), $1800 \mathrm{~cm}^{-1}(\mathrm{C}=\mathrm{O}$ bending $), 1736 \mathrm{~cm}^{-1}(\mathrm{C}=\mathrm{O}$ bending), $1618 \mathrm{~cm}^{-1}(\mathrm{C}=\mathrm{C}$ bending $)$ of aromatic ring, 1522.52 ( $\mathrm{CN}$ bending), $1455.99 \mathrm{Cm}^{-1}(\mathrm{C}-\mathrm{C}$ bending), beak at $1165.76 \mathrm{~cm}^{-1}$ expressed $\mathrm{C}=\mathrm{O}$. The extract had aromatic ring, $\mathrm{O}-\mathrm{H}, \mathrm{C}=\mathrm{O} \mathrm{C}=\mathrm{C}$ as well as $\mathrm{CN}$ group through infrared spectrum analysis. These were clear from the above data that is catechin structure.

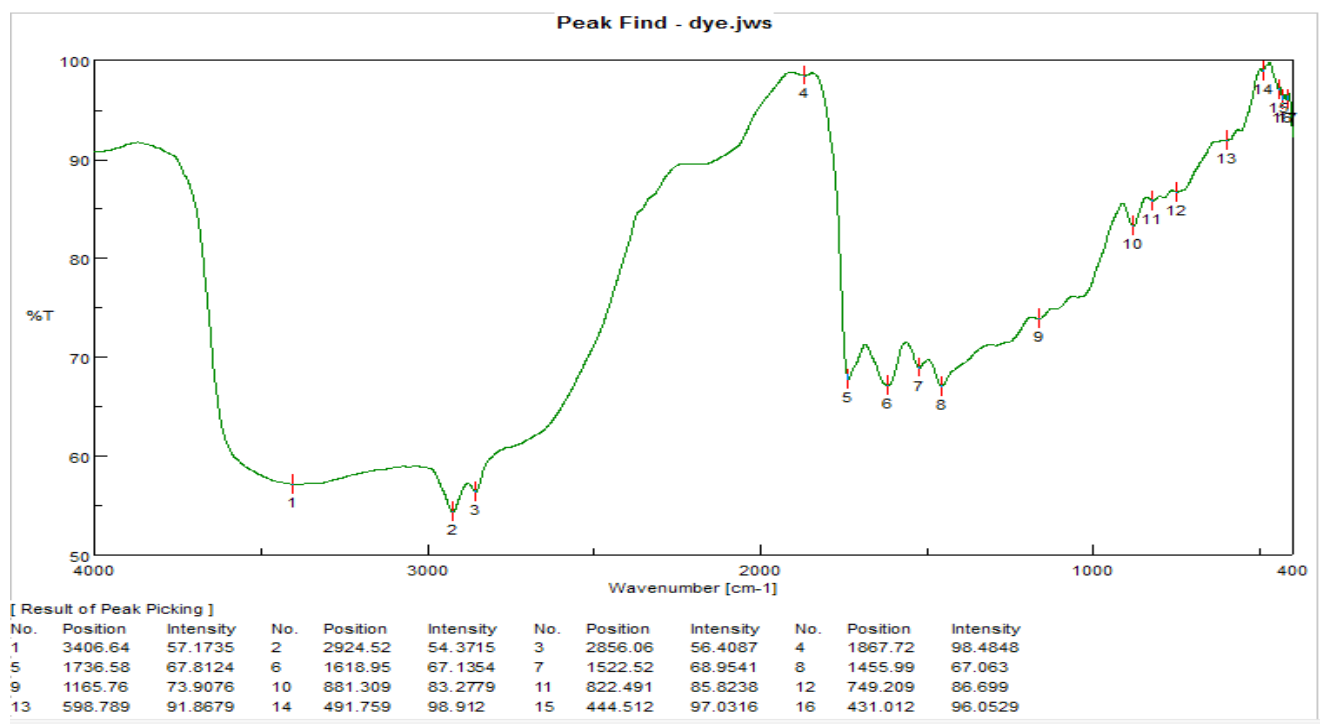

Fig. 1. Infrared spectra of peanut red skin extract. 
FT-IR spectra of non-dyedwool (blank) and dyed woolen fabrics were given in Fig. 2. Wool fabric contains more than 18 amino acids. Carboxyl $(-\mathrm{COOH})$, amino $\left(-\mathrm{NH}_{2}\right)$, and hydroxyl $(-\mathrm{OH})$ groups are the main functional groups of wool. FTIR spectra of wool fabrics showed characteristic absorption peaks particular for peptide bond[10][8][33, 34] specified as amide-I,
amide-II, and amide-III bands[35]. The IR spectra of wool fabric (blank) showed specific absorption bands: a broad one in the range of 3448-2966 $\mathrm{cm}^{-1}$ (-NH-stretching, $-\mathrm{SH}$ and $\mathrm{OH}$ stretching), strong peaks at 1690,1562 , and $1304 \mathrm{~cm}^{-1}$ are referring to amide $\mathrm{I}$, amide $\mathrm{II}$, and $-\mathrm{C}-\mathrm{N}$ stretching of amide III, respectively[36].

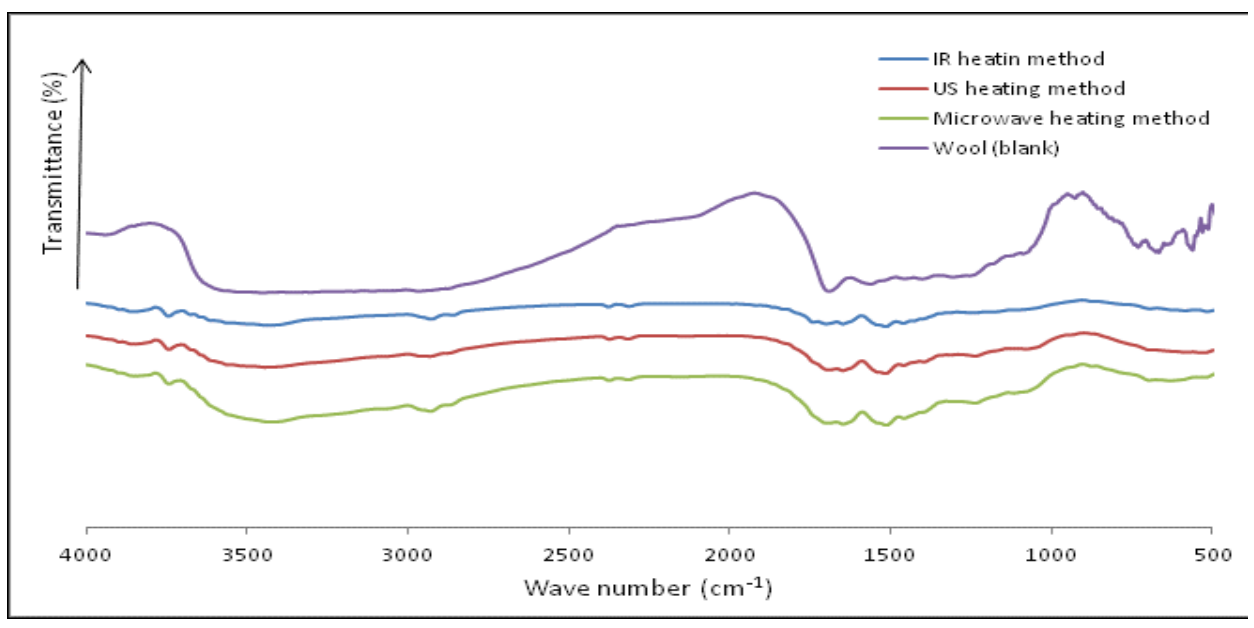

Fig. 2. Infrared spectra of dyed wool fabric with peanut red skin extract using IR, ultrasonic and microwave heating method.

There was a remarkable change in the peaks between non dyed wool (blank) and dyed wool. Whole characteristic peaks of non-dyed wool fabric (blank) were found in the dyed wool fabric with lower intensities. Low intensity and shifting of peaks related to amide-I and $\mathrm{C}-\mathrm{N}$ stretching frequency of amide-III bands of dyed wool fabrics at $3648 \mathrm{~cm}^{-1}$ and $1278 \mathrm{~cm}^{-1}$ were observed. Additionally new peaks at 1496 and $2877 \mathrm{~cm}^{-1}$ are recorded. These are finding indicate to the involvement of amino groups in the interaction between wool fabric and colorant in the peanut red skin extract $[33,34]$ (see Scheme 1).

\section{Antibacterial property}

Peanut red skin extract possess significant antimicrobial activity especially those containing natural tannins, curcuminoids, quinines etc. and which persist after application on textile fabric [37]. Antimicrobial activity of peanut red skin extract is dependent on chemical structure and functional groups present in the peanut red skin extract and fastness properties of wool dyed fabrics. Hence the antimicrobial properties of dyedwool fabrics against both $\mathrm{S}$. aureus $\left(\mathrm{G}^{+}\right)$ bacteria, K. Pneumoniae $\left(\mathrm{G}^{-}\right)$bacteria and $\mathrm{C}$. albicans (Fungi) were studied by optical density method and data were introduced in Table 9.
From data in Table 9, for all heating methods (IR, Ultrasonic and Microwave), the blank samples showed better antimicrobial activity comparing to the mordanting samples. It is known that there is a considerable relation between the release amount of materials and its antimicrobial potency, as higher release is resulted in higher microbial reduction [38-40]. From the fastness properties results in Table 7, the blank samples exhibited less wash fastness which reflects higher release of peanut red skin extract from fabrics surfaces. The antimicrobial activity of peanut red skin extract is a result of methoxy and hydroxyl groups which exist in its structure according to literature [37, 41]. Hence the higher microbial reduction observed for un-mordanted fabrics is attributed to the antimicrobial effect of peanut red Skin extract via higher release.

However, good fastness observed for mordanted fabrics resulted in much lower release and consequently lessen the microbial viability. Both of mordants (alum and $\mathrm{Fe}_{2} \mathrm{SO}_{4}$ ) have no significant difference in microbial reduction by considering the results after washing.

The antimicrobial properties against bacteria were found to be greater than that of fungi and 
the reduction in S. aureus $\left(\mathbf{G}^{+}\right)$bacteria was higher than K. Pneumoniae (G-) bacteria. This could be attributed to the differences in the structure of bacteria and fungi [42].

TABLE 9. Antibacterial activity of wool fabric dyed with natural coloring matter extracted from Peanut red Skin using different heating methods after 10 washing cycles.

\begin{tabular}{|c|c|c|c|c|}
\hline \multirow{4}{*}{$\begin{array}{l}\text { Heating } \\
\text { methods }\end{array}$} & \multirow{4}{*}{ Sample } & \multicolumn{2}{|c|}{ Total bacteria count $(\% \mathrm{R})$} & \multirow{2}{*}{$\begin{array}{l}\text { Total fungal count }(\% \mathbf{R}) \\
\text { Candida albicans } \\
\text { (Fungi) }\end{array}$} \\
\hline & & $\begin{array}{l}\text { Staphylococcus } \\
\text { Aureus }\left(\mathbf{G}^{+}\right) \\
\text {bacteria }\end{array}$ & $\begin{array}{c}\text { Klebsiella } \\
\text { Pneumoniae (G -) } \\
\text { bacteria }\end{array}$ & \\
\hline & & Reduction (\%) & Reduction (\%) & Reduction (\%) \\
\hline & & $10 \mathrm{~W}$ & $10 \mathrm{~W}$ & $10 \mathrm{~W}$ \\
\hline \multirow{3}{*}{ IR } & $\begin{array}{c}\text { Blank } \\
\text { (non-mordanted) }\end{array}$ & 60 & 65 & 38 \\
\hline & Pre alum & 18 & 48 & 26 \\
\hline & Pre $\mathrm{Fe}_{2} \mathrm{SO}_{4}$ & 31 & 10 & 10 \\
\hline \multirow{3}{*}{$\begin{array}{l}\text { Ultrasonic } \\
\text { heating }\end{array}$} & $\begin{array}{c}\text { Blank } \\
\text { (non-mordanted) }\end{array}$ & 71 & 43 & 51 \\
\hline & Pre alum & 32 & 57 & 37 \\
\hline & Sim. $\mathrm{Fe}_{2} \mathrm{SO}_{4}$ & 35 & 9 & 2 \\
\hline \multirow{3}{*}{$\begin{array}{c}\text { Microwave } \\
\text { heating }\end{array}$} & $\begin{array}{c}\text { Blank } \\
\text { (non-mordanted) }\end{array}$ & 32 & 14 & 43 \\
\hline & Pre alum & 38 & 40 & 53 \\
\hline & Sim. $\mathrm{Fe}_{2} \mathrm{SO}_{4}$ & 58 & 28 & 22 \\
\hline
\end{tabular}

Comparing between the three different heating methods, ultrasonic heating method exhibited the best antimicrobial reduction. For dyed mordanted fabrics using ultrasonic method, percentage of microbial reduction were $88 \%, 82 \% \mathrm{~S}$. aureus $\left(\mathbf{G}^{+}\right)$bacteria, $61 \%$ and $30 \%$ K. Pneumoniae (G) bacteria and $74 \%$ and $13 \% \mathrm{C}$. albicans (fungi) for alum and $\mathrm{Fe}_{2} \mathrm{SO}_{4}$, respectively. Using of IR heating method showed much higher microbial reduction than that of microwave heating one.

By studying the durability of dyed fabrics against repetitive washing cycles (10 washing cycles), reduction in microbial colonies was diminished after washings owing to leaching of dye in washing environment.

\section{Conclusion}

A convenient method for extraction of peanut red skin by using different heating methods namely; IR, ultrasonic and microwave heating methods were developed to realize the various red colors. The extraction of peanut red skin was successfully assisting of microwave heating as time and energy saving system, as well as the using of this extracted dye to wool fabric. A positive correlation was observed between extraction concentration, dye bath $\mathrm{pH}$, dyeing temperature, dyeing time and $\mathrm{K} / \mathrm{S}$ value. Among all factors, the effect of $\mathrm{pH}$ value on color characteristic was most noticeable. Results from fastness testing indicated that the blank dyed samples exhibited less wash fastness which reflects higher release of peanut red skin extract from fabrics surfaces and gave excellent antibacterial property as a result of this release. However, good fastness observed for mordanted fabrics resulted in much lower release and consequently lessen the microbial viability. Above all, peanut red skin as a natural dye with medical function is deserved of further study.

\section{$\underline{\text { References }}$}

1. Ballard T.S., Mallikarjunan P., Zhou K., and O'Keefe S.F., Optimizing the extraction of phenolic antioxidants from peanut skins using response surface methodology. Journal of Agricultural and Food Chemistry; 57 (8), 3064-72 (2009).

2. Ballard T.S., Mallikarjunan P., Zhou K. and Egypt.J.Chem. Special Issue (2017) 
O'Keefe S., Microwave-assisted extraction of phenolic antioxidant compounds from peanut skins. Food Chemistry, 120 (4), 1185-92 (2010).

3. Lou H., Yuan H., Ma B., Ren D., Ji M and Oka S., Polyphenols from peanut skins and their free radical-scavenging effects. Phytochemistr, 65 (16), 2391-9, (2004).

4. Sarnoski P.J., Johnson J.V., Reed K.A., Tanko J.M. and O'Keefe S.F., Separation and characterisation of proanthocyanidins in Virginia type peanut skins by LC-MSn. Food Chemistry; 131 (3), 927-39 (2012).

5. Tsujita T., Shintani T. and Sato H., Preparation and characterisation of peanut seed skin polyphenols. Food Chemistry, 151, 15-20 (2014).

6. Rice-Evans C., Flavonoids and isoflavones: absorption, metabolism, and bioactivity, Free radical biology \& medicine, 36 (7), 827-8 (2004).

7. Yu J., Ahmedna M. and Goktepe I., Effects of processing methods and extraction solvents on concentration and antioxidant activity of peanut skin phenolics. Food Chemistry, 90 (1-2), 199-206 (2005).

8. Yu J., Ahmedna M., Goktepe I. and Dai J., Peanut skin procyanidins: Composition and antioxidant activities as affected by processing. Journal of Food Composition and Analysis, 19 (4), 364-71 (2006).

9. Yu J., Ahmedna M. and Goktepe I., Potential of peanut skin phenolic extract as antioxidative and antibacterial agent in cooked and raw ground beef. International Journal of Food Science \& Technology, 45 (7), 1337-44(2010).

10. Jeong S.M., Kim S.Y., Kim D.R., Jo S.C., Nam K.C. and Ahn D.U., et al., Effect of heat treatment on the antioxidant activity of extracts from citrus peels. Journal of Agricultural and Food Chemistry, 52 (11), 3389-93 (2004).

11. Constanza K.E., White B.L., Davis J.P., Sanders T.H. and Dean L.L., Value-added processing of peanut skins: antioxidant capacity, total phenolics, and procyanidin content of spray-dried extracts. Journal of Agricultural and Food Chemistry, 60 (43), 10776-83 (2012).

12. Ma Y., Kerr W.L., Swanson R.B., Hargrove J.L. and Pegg R.B., Peanut skins-fortified peanut Egypt.J.Chem. Special Issue (2017) butters: Effect of processing on the phenolics content, fibre content and antioxidant activity. Food Chemistry, 145, 883-91 (2014).

13. Alencar S.M., Oldoni T.L.C., Castro M.L., Cabral ISR, Costa-Neto C.M. and Cury J.A., et al. Chemical composition and biological activity of a new type of Brazilian propolis: Red propolis. Journal of Ethnopharmacology, 113 (2), 278-83 (2007).

14. Appeldoorn M.M., Sanders M., Vincken J.P., Cheynier V., Le Guernevé C. and Hollman P.C.H., et al. Efficient isolation of major procyanidin A-type dimers from peanut skins and B-type dimers from grape seeds. Food Chemistry; 117 (4),713-20 (2009).

15. Francisco M.L.D. and Resurreccion A.V.A., Development of a reversed-phase high performance liquid chromatography (RPHPLC) procedure for the simultaneous determination of phenolic compounds in peanut skin extracts. Food Chemistry, 117 (2), 356-63 (2009).

16. Francisco M.L.L.D. and Resurreccion A.V.A. Total phenolics and antioxidant capacity of heat-treated peanut skins. Journal of Food Composition and Analysis, 22 (1), 16-24 (2009).

17. Lou H., Yamazaki Y., Sasaki T., Uchida M., Tanaka H, Oka S., A-type proanthocyanidins from peanut skins, Phytochemistry, 51 (2), 297-308 (1999).

18. Moraes-de-Souza R.A., Oldoni T.L.C., Regitano-d'Arce M.A.B. and Alencar S.M., Antioxidant activity and phenolic composition of herbal infusions consumed in Brazil activid ad antioxidante y compuestos fenólicos en infusiones herbarias consumid as en Brasil, Ciencia y Tecnologia Alimentaria, 6 (1), 41-7 (2008).

19. Pizzolitto R.P., Dambolena J.S., Zunino M.P, Larrauri M., Grosso N.R. and Nepote V., et al., Activity of natural compounds from peanut skins on Fusarium verticillioides growth and fumonisin B1 production. Industrial Crops and Products, 47, 286-90 (2013).

20. Balde E.S., Megalizzi V., Traore M.S., Cos P., Maes L. and Decaestecker C., et al., In vitro antiprotozoal, antimicrobial and antitumor activity of Pavetta crassipes K. Schum leaf 
extracts, J Ethnopharmacol, 130 (3), 529-35 (2010).

21. Al-Mousawi S., El-Apasery M. and Elnagdi M., Microwave assisted dyeing of polyester fabrics with disperse dyes. Molecules, 18 (9), 11033 (2013).

22. Öner E, Büyükakinci Y. and Sökmen N., Microwave-assisted dyeing of poly(butylene terephthalate) fabrics with disperse dyes. Color Technol, 129 (2),125-30 (2013).

23. Ahmed N.E. and El-Shishtawy R., The use of new technologies in coloration of textile fibers. J Mater Sci., 45 (5), 1143-53 (2010).

24. Bhat N.V., Kale M.J. and Gore A.V., Microwave radiations for heat-setting of polyester fibers, Journal of Engineered Fibers and Fabrics, 4(4), 1-6 (2009).

25. Haggag K., Ragheb A., Nassar S. H., Hashem M., Sayed H. El, I. AE-T., A Review Article of Microwave Irradiation and its Application in Textile Industries: Science Publishing Group (2014).

26. Hanna H.L., Haggag K. and El-Shemy N.S., Effect of microwave irradiation of properties of polyamide fabric. $18^{\text {th }}$ Egyptian International Chemical Conference, Chemistry of Human Needs. Hurghada, Egypt (2009).

27. Kappe C.O., Stadler A. and Dallinger D., Microwaves in Organic and Medicinal Chemistry. Weinheim, Germany: Wiley-VCH Verlag Gmb H \& Co. KGaA (2012).

28. Nourmohammadian F. and Gholami M.D., An investigation of the dyeability of acrylic fiber via microwave irradiation. Progress In Color, Colorants And Coatings, 1 (1), 57-63 (2008)

29. Tests for colour fastness: Colour Fastness to washing Test Textiles Basel: ISO (1989).

30. Tests for colour fastness: Colour fastness to artificial light: Xenon arc fading lamp test Textiles Basel: ISO (1988).

31. Tests for colour fastness: Colour fastness to rubbing. Textiles. Basel: ISO; (1987).

32. Hwang E.K., Lee Y.H. and Kim H.D., Dyeing, fastness, and deodorizing properties of cotton, silk, and wool fabrics dyed with gardenia, coffee sludge, Cassia tora. L., and pomegranate extracts , Fibers Polym, 9(3),334-40 (2008).
33. Rather L.J, Shahid-ul-Islam and Mohammad F., Study on the application of Acacia nilotica natural dye to wool using fluorescence and FTIR spectroscopy. Fibers and Polymers, 16 (7), 1497-505 (2015).

34. Shahid M., Ahmad A., Yusuf M, Khan M.I., Khan S.A.and Manzoor N., et al. Dyeing, fastness and antimicrobial properties of woolen yarns dyed with gallnut (Quercus infectoria Oliv.) extract. Dyes and Pigments, 95 (1), 53-61 (2012).

35. Wojciechowska E., Włochowicz A. and Wesełucha-Birczyńska A., Application of Fourier-transform infrared and Raman spectroscopy to study degradation of the wool fiber keratin. Journal of Molecular Structure, 511-512, 307-18 (1999).

36. Ebrahimi I. and Parvinzadeh Gashti M., Extraction of juglone from Pterocarya fraxinifolia leaves for dyeing, anti-fungal finishing, and solar UV protection of wool,Coloration Technology, 131(6),451-7 (2015).

37. Harish T, Pratibha S, Kumar M, Pradeep S., Evaluation of various techniques for extraction of natural colorants from pomegranate rindUltrasound and enzyme assisted extraction. INDIAN J FIBRE TEXT, 35 (3), 272- 6 (2010).

38. Emam H.E., Saleh N.H., Nagy K.S. and Zahran M.K., Functionalization of medical cotton by direct incorporation of silver nanoparticles, International Journal of Biological Macromolecules, 78, 249-56 (2015).

39. Emam H.E., Rehan M., Mashaly H.M., Ahmed H.B., Large scaled strategy for natural/synthetic fabrics functionalization via immediate assembly of AgNPs, Dyes and Pigments, 133,173-83 (2016).

40. Emam H.E., Saleh N.H., Nagy K.S. and Zahran M.K., Instantly AgNPs deposition through facile solventless technique for poly-functional cotton fabrics, International Journal of Biological Macromolecules, 84, 308-18 (2016).

41. Ammayappan L. and Jeyakodi Moses J., Study of antimicrobial activity of aloevera, chitosan, and curcumin on cotton, wool, and rabbit hair, Fibers and Polymer, 10(2), 161-6 (2009).

42. Kanchana R. , Fernandes A., Bhat B. and Egypt.J.Chem. Special Issue (2017) 
Budkule S, Dyeing of textiles with natural dyes - an eco-friendly approach, International Journal of ChemTech Research, 5 (5), 2102-9 (2013).

(Received 10/9/2017;

accepted 19/12/2017)

\section{النشاط المضاد للميكروبات للأقمشة الصوفية المصبوغة بالصبغة المستخلصة من قشرة

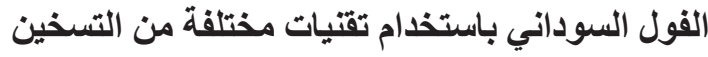

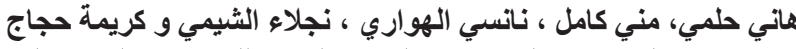

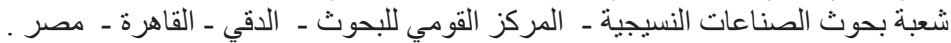

أهتمت هذه الدراسة بأستخلاص صبغات لونية من قثرة الفول السوداني الحمر اء واستخدامها قي صباغة

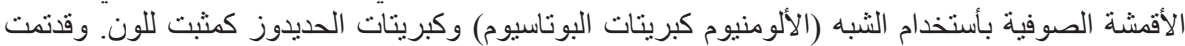

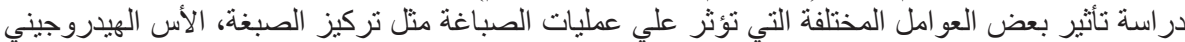

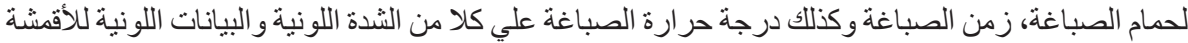

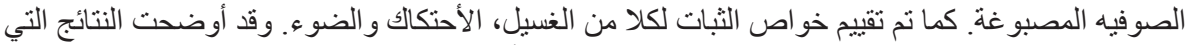

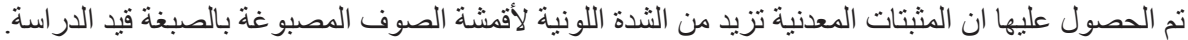

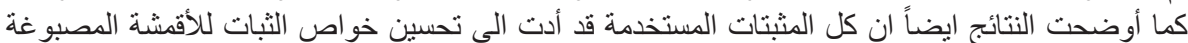

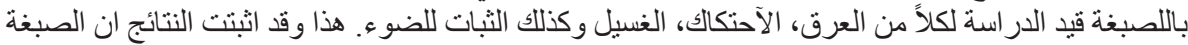

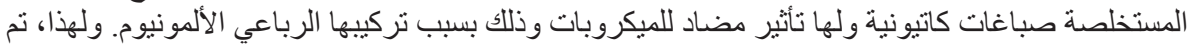

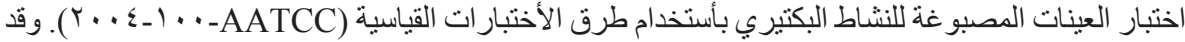

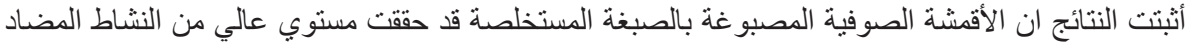

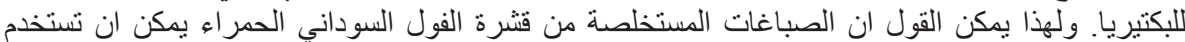

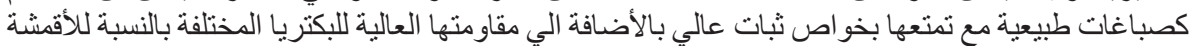

$$
\text { الصوفية. }
$$

